УДК 662.613+628.512

\title{
SELECTION OF THE TECHNOLOGY \\ OF DESULFURIZATION OF FLUE GASES \\ FOR UKRAINIAN COAL-BURNING \\ THERMAL POWER PLANTS
}

I. Volchyn, L. Haponych, I. Zhoran

National University of Food Technologies

\begin{tabular}{l}
$\quad$ Key words: \\
Power industry \\
Ecology \\
Thermal power plant \\
Flue gases \\
Contaminants \\
Sulfur \\
Technology \\
Cleaning \\
Desulfurization \\
\hline
\end{tabular}

Article history:

Received 04.07.2018

Received in revised form

24.07.2018

Accepted 15.08.2018

Corresponding author:

I. Volchyn

E-mail:

npnuht@ukr.net

\begin{abstract}
The concentration of sulfur dioxide in flue gases of thermal power plants after January 1, 2018 must be no higher than $200 \mathrm{mg} / \mathrm{nm}^{3}$ for existing plants and $150 \mathrm{mg} / \mathrm{nm}^{3}$ for those being constructed, as follows from Directive 2010/75/EU and order of Ministry of Ecology and Natural Resources of Ukraine No. 62 from February 16, 2018. Nowadays, the level of $\mathrm{SO}_{2}$ emission at Ukrainian thermal power plants (TPP) exceeds these ultimate values by $6-18$ times. This fact requires to introduce new, efficient technologies of gas cleaning. The selection of specific technologies of gas cleaning must be based on the principles of technological, economical and ecological expediency. These technologies must correspond to the criterion of "best available technologies".
\end{abstract}

The aim of this work was to determine the necessary degree of sulfur refinement of flue gases and select the priority method of sulfur refinement for its introduction at Ukrainian plants.

To realize this aim, we analyzed the present methods and technologies of cleating flue gases from $\mathrm{SO}_{2}$ as well as calculated and generalized gross and specific emission of sulfur dioxide in flue gases of TPP during 2013-2016. We astablished that the specific concentration of sulfur dioxide in dry flue gases at Ukrainian coal-burning TPP in 20132016 was $2500-7200 \mathrm{mg} / \mathrm{nm}^{3}$ depending on fuel grade, its sulfur content, and method of slag removal, and the gross emission of sulfur dioxide attains $106 \mathrm{t}$. We showed that the level of specific concentrations of sulfur dioxide in flue gases at Ukrainian coal-burning TPP requires to provide the level of cleaning no lower than $92-98 \%$. As the promising technology for introduction at Ukrainian coal-burning TPP, we should select the technology of wet lime desulfurization, despite high investment up to $200 € / \mathrm{kW}$.

DOI: $10.24263 / 2225-2924-2018-24-4-18$ 


\title{
ВИБІР ТЕХНОЛОГІЇ ДЕСУЛЬФУРИЗАЦІї ДИМОВИХ ГАЗІВ ДЛЯ УКРАЇНСЬКИХ ВУГІЛЬНИХ ТЕПЛОВИХ ЕЛЕКТРОСТАНЦІЙ
}

\author{
І.А. Вольчин, Л.С. Гапонич, І.П. Згоран \\ Національний університет харчових технологій
}

Концентрація діоксиду сірки в димових газах спалювальних установок після

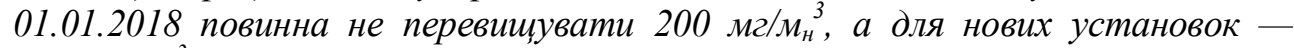
150 мг/нм $^{3}$, як того вимагають Директива 2010/75/EU та наказ Мінприроди України № 62 від 16.02.2018. Сьогодні рівень викидів $\mathrm{SO}_{2}$ на ТЕС України перевищує иі граничні значення в 6-18 разів. Це потребує впровадження сучасних ефективних технологій газоочищення. Вибір конкретних технологій газоочищення повинен базуватися на принципах технологічної, економічної та екологічної доиільності. Ці технологї повинні відповідати європейському критерію «Найкращі доступні технологї̈».

3 огляду на вищевикладене у статті визначено необхідний ступінь сіркоочищення димових газів та пріоритетний метод сіркоочищення для впровадження на ТЕС України. Для цъього було виконано аналіз сучасних методів і технологій очищення димових газів від $\mathrm{SO}_{2}$, розрахунок і узагальнення валових та питомих викидів діоксиду сірки у димових газах TЕС у 2013-2016 рр. Встановлено, щуо значення питомих конщентращій діоксиду сірки в сухих димових газах на ТЕС Украӥни у 2013-2016 рр. залежно від марки палива, його сірчистості та способу шлаковидалення в котлі були в діапазоні 2500

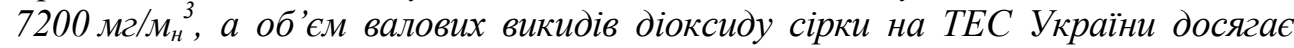
1000 тис. тонн. Показано, щзо рівень питомих конщентращій діоксиду сірки в димових газах українських вугільних ТЕС вимагає рівня ефективності очистки вище 92-98\%. Перспективною технологією для впровадження на ТЕС України є технологія мокрої вапнякової десульфуризації з примусовим окисленням, незважаючи на високі капітальні затрати, - до 200 Свро/кВт.

Ключові слова: енергетика, екологія, теплова електростанція, димові гази, икідливі речовини, сірка, технологія, очистка, десульфуризація.

Постановка проблеми. Енергетика є однією з головних складових економіки країни. Інтенсифікація розвитку вимагає подальшого збільшення виробництва електроенергії, що призводить до надмірного екологічного навантаження на природу. Особливо це стосується теплових електростанцій (ТЕС), на яких щороку спалюються мільйони тонн палива, при цьому утворюються великі обсяги шкідливих викидів золи, оксидів сірки та азоту.

Україна $є$ активним учасником міжнародного кліматичного процесу [13]. Національну екологічну політику країни спрямовано на забезпечення імплементації положень екологічного законодавства країн ЄС за напрямами обмеження шкідливих викидів і запобігання глобальній зміні клімату [4]. Україна як повноправний член Енергетичного співтовариства повинна забезпечити з 01.01.2018 дотримання вихідної концентрації діоксиду сірки в ди- 
мових газах від існуючих вугільних ТЕС та ТЕЦ не вище $200 \mathrm{мг} / \mathrm{M}_{\mathrm{H}}^{3}$, а для нових енергоблоків - $150 \mathrm{мг} / \mathrm{M}_{\mathrm{H}}{ }^{3}$, як цього вимагають Директива 2010/75/EU та наказ Мінприроди України № 62 від 16.02.2018 [5; 6] шляхом впровадження найкращих доступних технологій: бути екологічно ефективними, економічно доступними і пройти промислову перевірку [7].

Сьогодні рівень викидів $\mathrm{SO}_{2}$ на ТЕС України суттєво перевищує ці граничні значення [8]. Кардинального покращання екологічного стану в теплоенергетиці України можна досягти шляхом заміни практично всіх вугільних енергоблоків на сучасні з високими технологічними й екологічними показниками, але на це потрібні величезні кошти, оскільки повинна надійно функціонувати Об'єднана енергетична система України, яка в перспективі має увійти до Енергетичної системи Свропи [8].

Метою статті: визначення необхідного ступеня сіркоочищення димових газів і вибір пріоритетного методу сіркоочищення для впровадження на ТЕС України.

Викладення основних результатів дослідження. Існуючий парк газоочисного устаткування на ТЕС України представлений лише пиловловлювачами сухими електрофільтрами та мокрими золовловлювачами, які вводилися в експлуатацію одночасно з основним устаткуванням енергоблоків. Їхні проектні показники ефективності відповідають екологічним вимогам 40-60-річної давності, а тривалий час експлуатації призвів до значного падіння ефективності, вони і фізично, і морально застаріли [8-11]. На жодній ТЕС не споруджено установки очищення димових газів від діоксиду сірки. Крім того, українські вугільні ТЕС переважно оснащені котлами 3 рідким шлаковидаленням (РШВ), ефективність внутрішньопаливневого зв'язування сірки в яких становить 5,0\%.

Тільки на енергоблоці ст. № 4 Старобешівської ТЕС 3 котлом циркулюючого киплячого шару було досягнуто європейських екологічних показників: викиди $\mathrm{NO}_{x}, \mathrm{SO}_{x}<200$ мг $/ \mathrm{M}_{\mathrm{H}}{ }^{3}$, втрати теплоти через механічний недопал вуглецю $q_{4}<4 \%$, витрати умовного палива - 345 г/кВтг відпущеної електроенергії [8; 9]. Завдяки низькій робочій температурі горіння і подачі в паливо разом 3 вугіллям вапняку досягаються низькі викиди оксидів азоту й сірки, а летка зола та тверді продукти десульфуризації ефективно вловлюються в сучасному електрофільтрі.

Системи сіркоочищення димових газів від сірки були представлені в Україні дослідно-промисловими установками сухої десульфуризації, спорудженими на енергоблоці ст. № 1 Зуївської ТЕС і енергоблоці ст. № 7 Курахівської ТЕС $з$ ефективністю близько 60\% при використанні вапна й близько $30 \%$ при використанні вапняку. Крім того, часткове видалення $\mathrm{SO}_{2} 3$ димових газів має місце в мокрих золовловлювачах. На сьогодні в мокрих золовловлювачах уловлюється від 7 до 10\% діоксиду сірки завдяки лужноземельним складовим золи.

На часі проведення докорінної реконструкції або заміни більшості генеруючих потужностей пиловугільних енергоблоків ТЕС України [8; 9]. Ці заходи обов'язково повинні включати встановлення установок десульфу- 
ризації димових газів (ДДГ). На сьогодні проведено реконструкцію близько $20 \%$ вугільних енергоблоків ТЕС, але при ії проведенні невирішені питання приведення екологічних характеристик до сучасних вимог. Решта блоків підтримується в працездатному стані за рахунок капітальних і поточних ремонтів, але їх зношеність постійно зростає і сягає загрозливої межі з точки зору можливості їх подальшої експлуатації без проведення реконструкції. В планах реконструкції на 2019 р. передбачено реалізацію всього одного пілотного проекту з будівництва сіркоочисної установки на енергоблоці ст. № 2 Трипільської ТЕС. Планується використання технології напівсухої сіркоочистки ЦКШ Rafako [8].

Вибір конкретних технологій газоочищення повинен базуватися на принципах технологічної, економічної та екологічної доцільності. Тобто ці технології повинні відповідати критерію «Найкращі доступні технології»: бути екологічно ефективними, економічно доступними і пройти промислову перевірку. Для зменшення негативного впливу на довкілля на ТЕС світу вже більше 60 років розробляють і експлуатують установки очищення димових газів [8]. Пріоритетними для теплоенергетики України мають бути технології сіркоочищення, що пройшли промислову перевірку на енергоблоках розвинутих країн світу.

Димові гази $є$ продуктом високотемпературної взаємодії складових палива 3 киснем повітря, тобто продуктом горіння. Основними складовими димових газів є вуглекислий газ $\mathrm{CO}_{2}$, водяна пара $\mathrm{H}_{2} \mathrm{O}$, діоксид сірки $\mathrm{SO}_{2}$ та молекулярний азот $\mathrm{N}_{2}$. Сірка у вигляді різних сполук у більших або менших кількостях входить до складу всіх твердих горючих копалин. Більша частина вугільних пластів Донбасу містить середньосірчисте $\left(S_{t}^{d}-1,6-2,5 \%\right)$ та сірчисте вугілля $\left(S_{t}^{d}-2,6-4,0\right)[10 ; 11]$. Мінеральні сірчані сполуки включають піритну $\mathrm{FeS}_{2}$ та сульфатну сірку. Інколи у вугільних шарах зустрічається елементна сірка. Крім того, сірка входить до складу органічних компонентів вугілля. Діоксид сірки $є$ основним продуктом окислення сірки органічної та сірки піритної, які є складовими вугілля.

Вугілля, що постачається на ТЕС України в останні роки, характеризується приведеним вмістом сірки в діапазоні 0,6-1,3 г/МДж. Для порівняння, середній приведений вміст сірки в американському напівбітумінозному вугіллі басейну річки Паупер складає 0,26 г/МДж, а в родовищі Північні Аппалачі - 2,39 г/МДж [12]. Згідно з американськими екологічними законами при вмісті сірки у вугіллі менше 0,30 г/МДж енергетичний котел можна експлуатувати без сіркоочистки. Тобто заміщення високосірчистого вугілля на малосірчисте дає можливість відмовитись від спорудження дорогого обладнання ДДГ.

Для запобігання шкідливому впливу діоксиду сірки на довкілля в світі розроблено багато промислових технологій ДДГ на ТЕС, які можна віднести до категорії найкращих доступних технологій. Найбільший інтерес представляють ті технології ДДГ, що здатні забезпечити ефективне зв'язування діоксиду сірки вище 96\% [6; 7]. Умовно технології ДДГ можна поділити на мокрі, сухі та напівсухі $[8 ; 14-16]$. 
Ефективність технологій сіркоочищення визначається фізико-хімічними особливостями відбування процесу, тривалістю перебування в реакційній зоні та площею поверхні контакту газоподібної й дисперсної фаз. Тому для збільшення площі реагування дуже часто використовують рециркуляцію дисперсної фази.

Найбільш поширеною технологією ДДГ є мокре сіркоочищення з використанням сорбентів із лужними властивостями - вапняку, вапна, сполук натрію, аміачної води, морської води тощо [8; 13; 14]. Хімічне зв'язування діоксиду сірки відбувається в спеціальному абсорбері - мокрому скрубері. Такі технології наявні на близько $80 \%$ потужностей сіркоочисних установок на TEC і відповідають сучасним європейським екологічним вимогам.

Перевагою всіх методів мокрого сіркоочищення $\epsilon$ високий ступінь очистки - більше $95 \%$ та висока надійність роботи устаткування. Істотним недоліком $є$ підвищений теплообмін між нагрітими відхідним газами та промивною рідиною. При цьому частина вологи розчину випарюється, а гази насичуються водяною парою та охолоджуються до температури нижче точки роси (близько $50^{\circ} \mathrm{C}$ ), що може призвести до конденсації водяної пари у димососі та димовій трубі. Тому перед викиданням димові гази мають підігріватися або в спеціальному підігрівнику, який використовує теплоту відхідних газів (до сіркоочистки), або викидатися в атмосферне повітря через градирню чи «мокру» димову трубу. Для більшості цих методів потрібне громіздке обладнання та високе споживання енергії на власні потреби.

На сьогодні близько 90\% з усіх мокрих установок ДДГ на ТЕС у всьому світі працює за мокрим вапняковим/вапняним методом. $€$ дуже багато його різновидів і варіацій, які полягають у різному технічному виконанні окремих елементів установки.

Проміжною ланкою між мокрими та сухими методами $є$ напівсухі методи, коли реакція зв'язування діоксиду сірки відбувається як у рідкій фазі на краплях вологи, що вводиться у потік димових газів (причому кількість введеної рідини значно менша кількості промивної рідини для мокрих скруберів), так і на поверхні частинок сорбенту або продукту [8; 14-17]. Вона визначається умовою для випарювання усієї вологи крапель за рахунок теплоти димових газів, але при цьому температура газів не повинна опуститися нижче за водяну точку роси. Сухий порошок, що залишився після випару вологи, має осаджуватися в золовловлювачах. Досвід промислового застосування напівсухих технологій ДДГ показав, що вони є найбільш придатними при спалюванні вугілля 3 малою сірчистістю на котлоагрегатах відносно невеликої потужності. Тоді висока вартість сорбенту та підвищена запиленість вихідного потоку димових газів перед золовловлювачем компенсуються низькими капітальними затратами та затратами на власні потреби. Недоліком $\epsilon$ низка практична цінність утвореного сухого субпродукту.

Високої ефективності сірковловлення (до 98\%) можна досягти при використанні напівсухої аміачної десульфуризації, коли продуктом буде сухий пилоподібний сульфат амонію $\left(\mathrm{NH}_{4}\right)_{2} \mathrm{SO}_{4}$, який можна використовувати як мінеральне добриво. Зважаючи на малий розмір частинок сульфату амонію, вихідним пиловловлювачем має бути рукавний фільтр [8]. 
Сухі методи ДДГ димових газів дають змогу досягти високої ефективності сіркоочистки - 98\%. Вони засновані на процесах адсорбції, тобто поглинанні газів на поверхні твердих тіл $[8 ; 13 ; 14]$. Як сорбенти, зазвичай, застосовують речовини, що мають пористу структуру й велику питому поверхню. Для поглинання діоксиду сірки застосовують оксиди й карбонати лужноземельних і лужних металів, а також активоване вугілля й різноманітні види коксів і напівкоксів.

Сухі методи допускають реакцію між діоксидом сірки й поглиначем при високих температурах $\left(540-1000^{\circ} \mathrm{C}\right)$, тобто введення поглинача в газовий потік може здійснюватися безпосередньо в паливну камеру або на самому початку конвективної шахти. При цьому продукти очищення змішуються 3 леткою золою і йдуть у відвал або використовуються як низькосортний будівельний матеріал.

Високу ефективність сіркоочищення та використання сорбенту показали реактори циркулюючого киплячого шару (ЦКШ) [8]. Багаторазове використання частинок сорбенту з частковим заповненням їх поверхні шаром субпродукту та звільненням від нього під час підготовки до подачі дає змогу у багато разів збільшити поверхню контакту фаз, таким чином зростає і швидкість реакції. Циркуляція сорбенту відбувається по колу: реактор ЦКШ золовловлювач - реактор ЦКШ. Сорбент вводиться у нижню частину абсорбера ЦКШ через систему сопел, туди ж надходять і забруднені димові гази через сопла Вентурі. Тривалість перебування димових газів в абсорбері ЦКШ становить близько 8 с. Після завершення процесу десульфуризації з верхньої частини абсорбера димові гази та тверді субпродукти надходять до золоуловлювача (циклону, тканинного фільтру чи електрофільтру), де відбувається сепарація газової та твердої фаз. Більша частина уловлених твердих продуктів повертаються у процес через систему підготовки сорбенту, менша частково направляється на утилізацію. Волога до абсорбера вводиться у вигляді крапель суспензії сорбенту або технічної води, які за час перебування в абсорбері ЦКШ мають висохнути, а вихідна температура димових газів повинна перевищувати температуру точки роси на $15-20^{\circ} \mathrm{C}$ при забезпеченні відносної вологості димових газів близько вище $40 \%$.

Для вибору технології сіркоочищення з метою дотримання поточних технологічних нормативів допустимих викидів $\mathrm{SO}_{2}$ та для вибору джерел постачання на вугільні ТЕС палива, яке відповідало б вимогам поточних технологічних нормативів допустимих викидів діоксиду сірки, необхідно мати інформацію 3 питомих і валових викидів діоксиду сірки на ТЕС. Тому становить інтерес питання оцінки вихідної концентрації $\mathrm{SO}_{2}$ у сухих відпрацьованих газах на основі характеристик вугілля.

Концентрацію діоксиду сірки при відомому елементному складі вугілля можна розрахувати за стандартною методикою [18; 19]. Але в реальних умовах партії вугілля, що постачаються на ТЕС, супроводжуються технічним аналізом. Дані технічного аналізу не дають змогу проводити розрахунки за стандартною методикою [18; 19], тому для розрахунків питомих об'ємів димових газів та концентрації в них $\mathrm{SO}_{2}$, що утворюються при спалюванні вугілля, використовувався метод, розроблений в IBE НАН України [20]. 
В останні роки частка вугілля в паливному балансі ТЕС становить $98 \%$, частка природного газу та мазуту, відповідно, $2 \%$ [10; 11]. При спалюванні природного газу та мазуту утворюється $1,5-2 \%$ від загального об'єму димових газів на ТЕС. Мазут, що постачається на ТЕС України, характеризується високим вмістом сірки, тому при його спалюванні на ТЕС концентрація діоксиду сірки в димових газах досягає 3500 мг $/ \mathrm{M}^{3}$.

Для визначення точних значень питомих і валових викидів діоксиду сірки на ТЕС в розрахунках необхідно враховувати об'єми димових газів і $\mathrm{SO}_{2}$, що утворюються при спалюванні вугілля, природного газу і мазуту:

$$
\begin{gathered}
V_{D F G}=V_{D F G}^{\text {вугіля }}+V_{D F G}^{\text {пр.газ }}+V_{D F G}^{\text {мазут }} ; \\
E_{\mathrm{SO}_{2}}=E_{\mathrm{SO}_{2}}^{\text {вугіля }}+E_{\mathrm{SO}_{2}}^{\text {мазут }},
\end{gathered}
$$

де $V_{D V G}$ - валовий викид сухих димових газів, що утворюється при спалюванні палива на ТЕС за рік, млрд м $^{3} ; V_{D F G}^{\text {вугіля }}-$ валовий викид сухих димових газів, що утворюється при спалюванні вугілля на ТЕС за рік, млрд м³ $V_{D F G}^{\text {пр.газ }}$ - валовий викид сухих димових газів, що утворюється при спалюванні природного газу на ТЕС за рік, млрд м ${ }^{3} ; V_{D F G}^{\text {мазут }}$ - валовий викид сухих димових газів, що утворюється при спалюванні мазуту за ТЕС за рік, млрд м³ $E_{\mathrm{SO}_{2}}$ - валовий викид $\mathrm{SO}_{2}$, що утворюється при спалюванні палива на ТЕС за рік, тис. т; $E_{\mathrm{SO}_{2}}^{\text {вугля }}$ - валовий викид $\mathrm{SO}_{2}$, що утворюється при спалюванні ву-

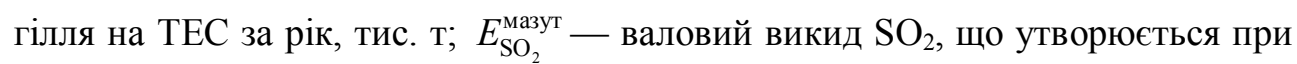
спалюванні мазуту на ТЕС за рік, тис. т.

Для розрахунку питомого об'єму сухих димових газів $V_{D F G}, \mathrm{M}_{\mathrm{H}}^{3} / \kappa \Gamma$ або $\mathbf{M}_{\mathrm{H}}{ }^{3} \mathbf{M}_{\mathrm{H}}{ }^{3}$, що утворюються при повному згорянні вугілля, природного газу $\mathrm{i}$ мазуту було використано формулу [18]:

$$
V_{D F G}=K \cdot Q_{i}^{r},
$$

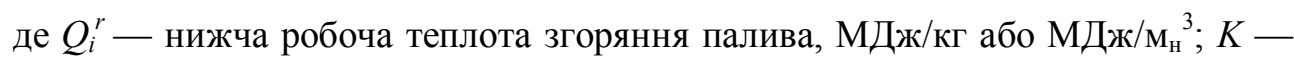
коефіцієнт, що враховує характер палива: для вугілля $K$ вибирається 3 [20] залежно від марки, для природного газу $K=0,345 \mathrm{~m}_{\mathrm{H}}{ }^{3} / \mathrm{MДж,} \mathrm{для} \mathrm{мазуту} K=$ 0,355 кг/МДж [18].

Питомий об'єм сухих димових газів з урахуванням наявності механічного недопалу визначався за формулою [20]:

$$
V_{D V G}\left(q_{4}\right)=V_{D V G}\left(1-q_{4} / 100\right) \text {. }
$$

Валовий викид $\mathrm{SO}_{2}$, що утворюється при спалюванні вугілля на ТЕС за рік, визначали за формулою:

$$
E_{\mathrm{SO}_{2}}^{\text {вугілля }}=c_{\mathrm{SO}_{2}}^{\text {вугіля }} \cdot V_{D V G}^{\text {вугіля }},
$$

де $c_{\mathrm{SO}_{2}}^{\text {вугля }}-$ концентрації діоксиду сірки в сухих димових газах, що утворюються при спалюванні вугілля на ТЕС, $\mathrm{Mг} / \mathrm{M}_{\mathrm{H}}{ }^{3}$. 
Концентрації діоксиду сірки в сухих димових газах, що утворюються при спалюванні вугілля, $c_{\mathrm{SO}_{2}}^{\text {вугля }}$, мг $/ \mathrm{M}_{\mathrm{H}}{ }^{3}$, визначали 3 [20] залежно від марки вугілля й типу шлаковидалення на ТЕС. Для урахування наявності механічного недопалу $\left(q_{4}>0\right)$ використовували формулу:

$$
c_{\mathrm{SO}_{2}}\left(q_{4}\right)=c_{\mathrm{SO}_{2}} /\left(1-q_{4} / 100\right) .
$$

Розрахункові методи визначення викиду забруднювальної речовини базуються на використанні показника емісії [19]. Формула для розрахунку валових викидів $\mathrm{SO}_{2}$, що утворюється при спалюванні мазуту на ТЕС за рік:

$$
E_{\mathrm{SO}_{2}}^{\text {мазут }}=10^{-6} k_{\mathrm{SO}_{2}}^{\text {мазут }} Q_{i}^{r} B^{\text {мазут }} \cdot 10^{-3},
$$

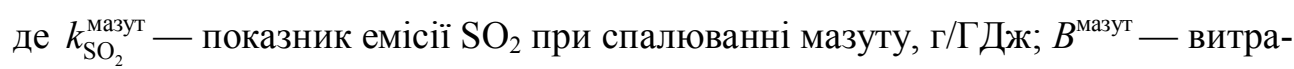
та мазуту за рік, т; $Q_{i}^{r}$ - нижча робоча теплота згоряння мазуту, МДж/кг.

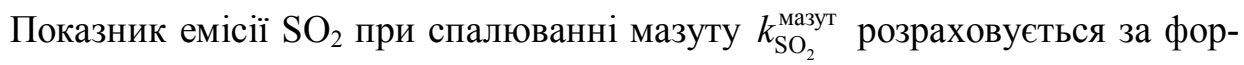
мулою:

$$
k_{\mathrm{SO}_{2}}^{\mathrm{Mazyт}}=\frac{10^{6}}{Q_{i}^{r}} \frac{2 \mathrm{~S}^{r}}{100}\left(1-\eta_{I}\right)\left(1-\eta_{I I} \beta\right),
$$

де $S^{r}$ - вміст сірки в мазуті на робочу масу, \%; $\eta_{I}-$ ефективність зв'язування сірки золою або сорбентом у енергетичній установці; $\eta_{I I}$ - ефективність очистки димових газів від оксидів сірки; $\beta$ - коефіцієнт роботи сіркоочисної установки.

Ефективність зв'язування оксидів сірки золою або сорбентом в енергетичній установці $\eta_{I}$ залежить від типу шлаковидалення і для котлів з РШВ становить 0,05, а для котлів з твердим шлаковидаленням (ТШВ) $-0,1$ [20]. Установки ДДГ відсутні на всіх ТЕС України, тому $\eta_{I I}=0$ та $\beta=0$.

Концентрацію діоксиду сірки в сухих димових газах, що утворюються при

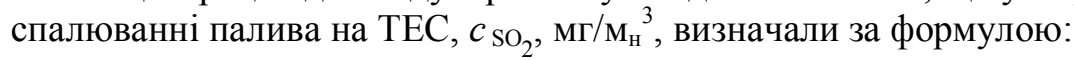

$$
c_{\mathrm{SO} 2}=\frac{E_{\mathrm{SO} 2}}{V_{D F G}} .
$$

За цим методом виконано розрахунки питомих і валових викидів сухих димових газів на всіх вугільних ТЕС України та концентрації в них $\mathrm{SO}_{2}$ у 2016 році. Для розрахунків використовувалася інформація з відпущеної ТЕС електроенергії, якості та витрати вугілля, природного газу та мазуту, що постачалося на ТЕC, $q_{4} 3$ офіційних звітів ТЕС. Отримані результати розрахунків узагальнено окремо для ТЕС, що спалюють низькореакційне вугілля (марки А та П), та для ТЕС, що спалюють високореакційне вугілля (марки Г та ДГ). Значення питомих і валових викидів димових газів, що утворюються при спалюванні вугілля, та концентрації в них $\mathrm{SO}_{2}$ на ТЕС України у $2013-$ 
2015 рр. взято 3 [10; 11]. Результати розрахунків та їх узагальнення наведено в табл. $1-5$.

Значення питомих концентрацій діоксиду сірки в сухих димових газах на TEC України у 2013-2016 pр. залежно від марки палива, його сірчистості (поставок) та способу шлаковидалення в котлі були в діапазоні 2500$7200 \mathrm{M \Gamma} / \mathrm{M}_{\mathrm{H}}^{3}$. Аналіз результатів показує, що в останні роки об'єм валових викидів діоксиду сірки на ТЕС України досягав 1000 тис. тонн. Зменшення валового викиду $\mathrm{SO}_{2}$ на ТЕС у 2015 р. до 800 тис. т пов'язано зі зменшення виробництва електроенергії більше ніж на 20,0\% порівняно з 2014 р., і на 30\%, порівняно з 2013 роком. Треба зазначити, що за Національним планом скорочення викидів (НПСВ) передбачається зменшення викидів $\mathrm{SO}_{2}$ на ТЕС України до 51 тис. т у 2028 р. [7].

Таблиця 1. Інформація про якість та витрати палива, $\mathbf{q}_{4}$, результати розрахунків питомих і валових викидів димових газів та діоксиду сірки на вугільних ТЕС України у 2013 році

\begin{tabular}{|c|c|c|c|c|c|c|c|c|c|c|c|c|c|c|c|c|c|c|c|c|}
\hline \multirow[b]{2}{*}{ TEC } & \multirow[b]{2}{*}{ 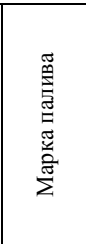 } & \multirow[b]{2}{*}{$\begin{array}{l}\stackrel{*}{*} \\
\text { 䍐 } \\
\text { 䍐 }\end{array}$} & \multirow[b]{2}{*}{$\begin{array}{l}a^{\circ} \\
\text { f }\end{array}$} & \multicolumn{8}{|c|}{ Для вугілля } & \multicolumn{4}{|c|}{ Для мазуту } & \multirow[b]{2}{*}{ 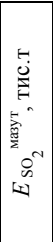 } & \multicolumn{2}{|c|}{ Для газу } & \multirow[b]{2}{*}{ 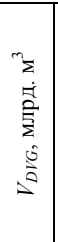 } & \multirow[b]{2}{*}{ 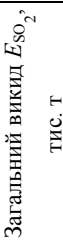 } \\
\hline & & & & 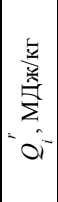 & $\begin{array}{l}0 \\
\square\end{array}$ & $\frac{0^{\circ}}{25}$ & 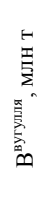 & 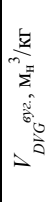 & 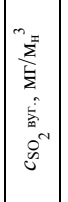 & 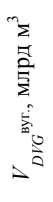 & 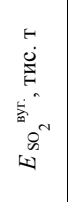 & 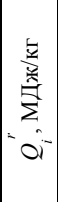 & $\begin{array}{c}0^{0} \\
-i s\end{array}$ & 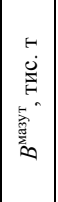 & 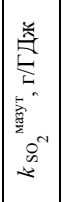 & & 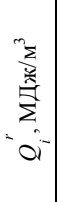 & 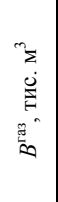 & & \\
\hline \multicolumn{21}{|c|}{ ПАТ «Донбасенерго» } \\
\hline $\begin{array}{l}\text { Старобе- } \\
\text { шівська }\end{array}$ & А, $\Pi$ & РШВ & 4,7 & 22,0 & 25,5 & 1,4 & 3,7 & 7,7 & 3233 & 28,9 & 93,3 & 39,6 & 2,2 & 0 & 1055 & 0 & 33,3 & 50,5 & 29,4 & 93,4 \\
\hline $\begin{array}{c}\text { Слов'ян- } \\
\text { ська }\end{array}$ & A & РШВ & 3,6 & 22,8 & 23,3 & 1,3 & 1,2 & 8,1 & 2816 & 9,4 & 26,4 & 31,9 & 1,5 & 0 & 917 & 0 & 33,8 & 11,9 & 9,5 & 26,4 \\
\hline \multicolumn{21}{|c|}{ ПАТ «Центренерго» } \\
\hline $\begin{array}{l}\text { Вуглегір- } \\
\text { ська }\end{array}$ & г, ДГ & РШВ & 0,2 & 22,5 & 23,2 & 3,3 & 1,0 & 8,0 & 7188 & 8,2 & 58,6 & 35,5 & 1,7 & 0 & 882 & 0 & 33,5 & 7,6 & 8,2 & 58,6 \\
\hline $\begin{array}{l}\text { Трипіль- } \\
\text { ська }\end{array}$ & А, П & РШВ & 6,6 & 22,9 & 22,9 & 1,5 & 2,2 & 7,9 & 3239 & 16,9 & 54,8 & 38,1 & 2,2 & 1,3 & 1076 & 0,05 & 34,2 & 11,6 & 17,0 & 54,8 \\
\hline Зміївська & $\mathrm{A}, \Pi$ & РШВ & 4,0 & 23,0 & 23,0 & 2,0 & 3,2 & 8,1 & 4252 & 25,7 & 109,3 & 35,8 & 1,8 & 1,9 & 934 & 0,06 & 33,6 & 58,8 & 26,4 & 109,4 \\
\hline \multicolumn{21}{|c|}{ ПАТ «ДТЕК Дніпроенерго» } \\
\hline $\begin{array}{c}\text { Криво- } \\
\text { різька }\end{array}$ & $\Pi$ & РШВ & 4,5 & 24,2 & 23,9 & 2,6 & 3,2 & 8,5 & 5686 & 27,5 & 156,1 & 40,2 & 1,8 & 2,0 & 828 & 0,07 & 33,8 & 25,7 & 27,8 & 156,2 \\
\hline $\begin{array}{l}\text { Придніп- } \\
\text { ровська }\end{array}$ & А, П & РШВ & 9,5 & 23,1 & 23,6 & 1,7 & 1,9 & 7,7 & 3892 & 14,9 & 58,14 & 37,1 & 1,5 & 1,3 & 788 & 0,04 & 33,5 & 72,1 & 15,7 & 58,2 \\
\hline $\begin{array}{c}\text { Запорізь- } \\
\text { ка }\end{array}$ & $\Gamma$, ДГ & РШВ & 0,3 & 22,1 & 22,3 & 2,6 & 2,6 & 7,89 & 5100 & 20,5 & 104,7 & 39,6 & 1,8 & 0 & 859 & - & 33,9 & 17,2 & 20,7 & 104,7 \\
\hline \multicolumn{21}{|c|}{ ПАТ «ДТЕК Західенерго» } \\
\hline $\begin{array}{c}\text { Бурштин- } \\
\text { ська }\end{array}$ & $\Gamma, Д Г$ & РШВ & 1,1 & 21,6 & 22,2 & 1,8 & 4,8 & 7,6 & 4006 & 36,2 & 144,8 & 40,2 & 1,9 & 0 & 903 & 0 & 33,7 & 68,4 & 36,9 & 144,8 \\
\hline $\begin{array}{c}\text { Добро- } \\
\text { твірська }\end{array}$ & $\Gamma, Д Г$ & ТШВ & 1,0 & 22,5 & 23,7 & 2,1 & 1,0 & 7,94 & 4336 & 7,7 & 33,5 & - & - & 0 & - & 0 & 34,0 & 3,2 & 7,8 & 33,5 \\
\hline $\begin{array}{c}\text { Ладижин- } \\
\text { ська }\end{array}$ & $\Gamma$, ДГ & РШВ & 0,4 & 21,3 & 21,2 & 2,1 & 2,8 & 7,58 & 4470 & 21,4 & 95,7 & 39,4 & 2,1 & 0 & 1003 & 0 & 32,9 & 18,5 & 21,6 & 95,7 \\
\hline \multicolumn{21}{|c|}{ ТОВ «ДТЕК Східенерго» } \\
\hline Зуївська & $\Gamma, Д Г$ & РШВ & 0,3 & 20,2 & 26,2 & 2,0 & 3,1 & 7,2 & 4462 & 22,5 & 100,2 & 36,9 & 1,8 & 0 & 947 & - & 34,0 & 13,1 & 22,6 & 100,2 \\
\hline $\begin{array}{l}\text { Курахів- } \\
\text { ська }\end{array}$ & $\begin{array}{c}\text { пром. } \\
\text { продукт } \\
\Gamma, Д Г \\
\end{array}$ & ТШВ & 1,8 & 18,9 & 34,9 & 1,8 & 3,8 & 6,6 & 4392 & 25,0 & 110,0 & 39,2 & 2,4 & 29,7 & 1083 & 1,26 & 34,0 & 10,7 & 25,6 & 111,3 \\
\hline $\begin{array}{c}\text { Луган- } \\
\text { ська }\end{array}$ & А, П & РШВ & 4,1 & 25,0 & 17,0 & 1,8 & 2,4 & 8,8 & 3613 & 20,7 & 74,9 & 40,1 & 1,3 & 2,2 & 621 & 0,06 & 34,0 & 32,6 & 21,1 & 75,0 \\
\hline Всього & & & & & & 1,9 & 36,8 & & & 285,4 & 220,4 & & & 38,4 & & 1,54 & & 402 & 290,4 & 1222,0 \\
\hline
\end{tabular}

*РШВ - рідке шлаковидалення, ТШВ - тверде шлаковидалення. 
Таблиця 2. Інформація про якість та витрати палива, результати розрахунків питомих і валових викидів сухих димових газів та діоксиду сірки на вугільних ТЕС України у 2014 році

\begin{tabular}{|c|c|c|c|c|c|c|c|c|c|c|c|c|c|c|c|c|c|c|c|c|}
\hline \multirow[b]{2}{*}{ TEC } & \multirow[b]{2}{*}{ 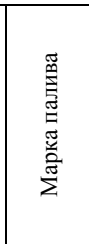 } & \multirow[b]{2}{*}{$\underset{⿱ ㇒}{\stackrel{*}{G}}$} & \multirow[b]{2}{*}{$\begin{array}{l}\stackrel{0}{0} \\
\text { f }\end{array}$} & \multicolumn{8}{|c|}{ Для вугілля } & \multicolumn{4}{|c|}{ Для мазуту } & \multirow[b]{2}{*}{ 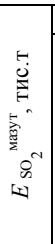 } & \multicolumn{2}{|c|}{ Для газу } & \multirow[b]{2}{*}{ 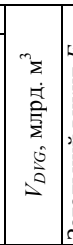 } & \multirow[b]{2}{*}{ 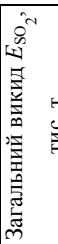 } \\
\hline & & & & 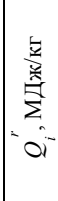 & $\therefore$ & $\therefore$ & 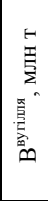 & 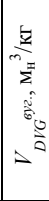 & 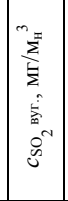 & 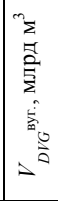 & 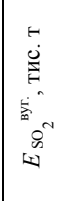 & 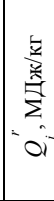 & $\begin{array}{l}\circ \\
-\infty\end{array}$ & 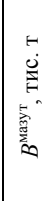 & 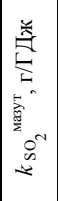 & & 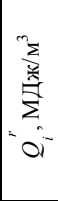 & 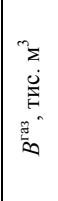 & & \\
\hline \multicolumn{21}{|c|}{ ПАТ «Донбасенерго» } \\
\hline \begin{tabular}{|c|} 
Старобе- \\
шівська
\end{tabular} & А, $\Pi$ & РШВ & 3,9 & 23,2 & 23,2 & 1,7 & 2,7 & 8,2 & 3643 & 22,3 & 81,3 & 39,1 & 1,4 & 0 & 660 & 0 & 33,3 & 33,7 & 22,7 & 81,3 \\
\hline \begin{tabular}{|c|} 
Слов'ян- \\
ська
\end{tabular} & A & РШВ & 2,2 & 23,4 & 22,2 & 1,2 & 0,6 & 8,4 & 2456 & 4,8 & 11,9 & 30,4 & 1,6 & 1,8 & 980 & 0,05 & 33,8 & 10,2 & 5,0 & 11,9 \\
\hline \multicolumn{21}{|c|}{ ПАТ «Центренерго» } \\
\hline \begin{tabular}{|c|} 
Вуглегір- \\
ська
\end{tabular} & $\Gamma$, ДГ & РШВ & 0,2 & 22,7 & 22,5 & 3,2 & 1,6 & 8,1 & 6963 & 13,0 & 90,6 & 36,0 & 1,7 & 0 & 903 & 0 & 33,6 & 7,7 & 13,1 & 90,6 \\
\hline \begin{tabular}{|c} 
Трипіль- \\
ська
\end{tabular} & А, $\Pi$ & РШВ & 7,12 & 22,2 & 24,6 & 1,4 & 1,8 & 7,6 & 3124 & 13,7 & 42,8 & 36,6 & 2,2 & 2,4 & 1115 & 0,09 & 34,1 & 90,0 & 14,7 & 42,9 \\
\hline Зміївська & $\mathrm{A}, \Pi$ & РШВ & 6,5 & 22,1 & 25,4 & 1,8 & 2,4 & 7,6 & 3975 & 18,1 & 71,9 & 32,9 & 1,3 & 3,3 & 740 & 0,08 & 33,5 & 52,0 & 18,7 & 72,0 \\
\hline \multicolumn{21}{|c|}{ ПАТ «ДТЕК Дніпроенерго» } \\
\hline $\begin{array}{c}\text { Криво- } \\
\text { різька }\end{array}$ & $\Pi$ & РШВ & 5,4 & 24,3 & 22,3 & 2,2 & 3,0 & 8,4 & 4716 & 25,5 & 120,4 & 39,7 & 1,7 & 1,9 & 823 & 0,06 & 33,8 & 26,4 & 25,9 & 120,5 \\
\hline \begin{tabular}{|c} 
Придні- \\
провська
\end{tabular} & , П & ШВ & 8,5 & 23,3 & 23,2 & 1,3 & 1,9 & 7,8 & 2916 & 15,0 & 43,7 & 36,3 & 1,5 & 0 & 801 & 0 & 33,7 & 70,0 & 15,7 & 43,7 \\
\hline Запорізька & $\Gamma, Д Г$ & РШВ & 0,3 & 21,3 & 24,5 & 1,8 & 2,5 & 7,6 & 3985 & 18,8 & 75,0 & 40,0 & 1,8 & 0 & 861 & 0 & 34,0 & 11,0 & 19,0 & 75,0 \\
\hline \multicolumn{21}{|c|}{ ПАТ «ДТЕК Західенерго» } \\
\hline \begin{tabular}{|c|} 
Буршти- \\
нська
\end{tabular} & Г, ДГ & РШВ & 1,1 & 21,3 & 24,1 & 1,9 & 4,9 & 7,5 & 4346 & 36,8 & 160 & 39,1 & 2,2 & 0 & 1037 & 0 & 33,7 & 44,0 & 37,3 & 160,0 \\
\hline $\begin{array}{c}\text { Добро- } \\
\text { твірська }\end{array}$ & Г, ДГ & ТШВ & 1,0 & 22,0 & 23,9 & 2,1 & 0,9 & 7,8 & 4448 & 7,1 & 31,5 & - & - & 0 & - & 0 & 34,1 & 9,8 & 7,1 & 31,5 \\
\hline \begin{tabular}{|c|} 
Ладижин- \\
ська
\end{tabular} & $\Gamma$, ДГ & РШВ & 0,4 & 20,4 & 24,1 & 1,6 & 2,7 & 7,3 & 3538 & 19,6 & 69,4 & 39,5 & 2,0 & 1,4 & 966 & 0,05 & 32,9 & 21,4 & 19,9 & 69,5 \\
\hline \multicolumn{21}{|c|}{ ТОВ «ДТЕК Східенерго» } \\
\hline Зуївська & $\Gamma, Д Г$ & РШВ & 0,3 & 20,3 & 26,7 & 2,0 & 2,1 & 7,2 & 45,62 & 15,1 & 68,9 & 39,5 & 1,8 & - & 855 & - & 34,0 & 11,3 & 15,2 & 68,9 \\
\hline $\begin{array}{c}\text { Курахів- } \\
\text { ська }\end{array}$ & \begin{tabular}{|c|} 
пром. \\
продукт \\
$\Gamma, Д Г$ \\
\end{tabular} & ТШВ & 2,0 & 17,9 & 36,0 & 1,6 & 3,3 & 6,3 & 4039 & 20,7 & 83,7 & 38,5 & 1,7 & 26,7 & 804 & 0,83 & 34,0 & 2,7 & 21,1 & 84,5 \\
\hline $\begin{array}{c}\text { Луган- } \\
\text { ська }\end{array}$ & А, $\Pi$ & РШВ & 4,4 & 24,9 & 17,3 & 1,6 & 2,1 & 8,8 & 3268 & 18,6 & 61,0 & 40,2 & 1,3 & 1,3 & 620 & 0,03 & 33,8 & 9,4 & 18,8 & 61,1 \\
\hline Всього & & & & 21,8 & 30,4 & 1,8 & 32,5 & & & 249,3 & 1012, & & & 38,8 & & 1,2 & & 394,0 & 254,2 & 1013,4 \\
\hline
\end{tabular}

*РШВ — рідке шлаковидалення, ТШВ — тверде шлаковидалення.

Табличя 3. Інформація про якість та витрати палива, результати розрахунків питомих і валових викидів сухих димових газів та діоксиду сірки на вугільних ТЕС України у 2015 році

\begin{tabular}{|c|c|c|c|c|c|c|c|c|c|c|c|c|c|c|c|c|c|c|c|c|}
\hline \multirow[b]{2}{*}{ TEC } & \multirow[b]{2}{*}{ 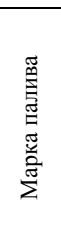 } & \multirow[b]{2}{*}{$\begin{array}{l}\stackrel{*}{\text { 罗 }} \\
\text { 㤩 }\end{array}$} & \multirow[b]{2}{*}{$\begin{array}{l}\text { d } \\
\text { f }\end{array}$} & \multicolumn{8}{|c|}{ Для вугілля } & \multicolumn{4}{|c|}{ Для мазуту } & \multirow[b]{2}{*}{ 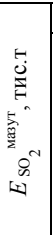 } & \multicolumn{2}{|c|}{ Для газу } & \multirow[b]{2}{*}{ 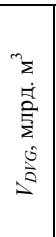 } & \multirow[b]{2}{*}{ 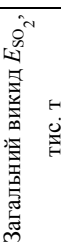 } \\
\hline & & & & 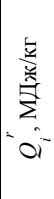 & $\therefore$ & $\therefore$ & 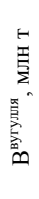 & 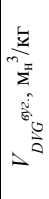 & 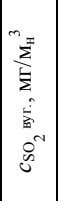 & 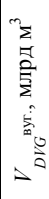 & 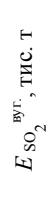 & 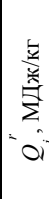 & $\begin{array}{l}a^{\circ} \\
-\infty\end{array}$ & 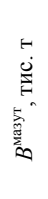 & 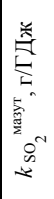 & & 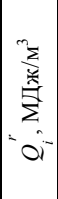 & 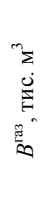 & & \\
\hline 1 & 2 & 3 & 4 & 5 & 6 & 7 & 8 & 9 & 10 & 11 & 12 & 13 & 14 & 15 & 16 & 17 & 18 & 19 & 20 & 21 \\
\hline \multicolumn{21}{|c|}{ ПАТ «Донбасенерго» } \\
\hline $\begin{array}{l}\text { Старобе- } \\
\text { шівська }\end{array}$ & $\mathrm{A}, \Pi$ & РШВ & 4,0 & 23,1 & 25,1 & 1,7 & 2,1 & 8,18 & 3736 & 17,2 & 64,4 & 39,8 & 1,7 & 0,88 & 798 & 0,03 & 33,3 & 6,7 & 17,3 & 64,4 \\
\hline $\begin{array}{l}\text { Слов'ян- } \\
\text { ська }\end{array}$ & A & РШВ & 2,9 & 23,6 & 22,5 & 1,5 & 1,1 & 8,42 & 3280 & 9,0 & 29,7 & 33,5 & 2,3 & 1,17 & 1279 & 0,05 & 33,9 & 14,4 & 9,1 & 29,7 \\
\hline
\end{tabular}


Продовження табл. 3

\begin{tabular}{|c|c|c|c|c|c|c|c|c|c|c|c|c|c|c|c|c|c|c|c|c|}
\hline 1 & 2 & 3 & 4 & 5 & 6 & 7 & 8 & 9 & 10 & 11 & 12 & 13 & 14 & 15 & 16 & 17 & 18 & 19 & 20 & 21 \\
\hline \multicolumn{21}{|c|}{ ПАТ «Центренерго» } \\
\hline $\begin{array}{c}\text { Вуглегір- } \\
\text { ська }\end{array}$ & $\Gamma, Д Г$ & РШВ & 0,2 & 22,4 & 23,9 & 3,1 & 2,0 & 7,97 & 6942 & 16,0 & 110,8 & 37,7 & 1,8 & 0,91 & 923 & 0,03 & 33,6 & 19,2 & 16,0 & 110,9 \\
\hline $\begin{array}{c}\text { Трипіль- } \\
\text { ська }\end{array}$ & А, $\Pi$ & РШВ & 5,9 & 23,4 & 23,8 & 1,5 & 1,3 & 8,09 & 3219 & 10,7 & 34,6 & 32,3 & 2,2 & 4,1 & 1300 & 0,17 & 34,1 & 44,0 & 10,8 & 34,7 \\
\hline Зміївська & $\mathrm{A}, \Pi$ & РШВ & 6,0 & 23,4 & 22,9 & 1,4 & 0,6 & 8,14 & 3057 & 4,5 & 13,7 & 29,5 & 1,3 & 2,14 & 858 & 0,05 & 35,6 & 15,7 & 4,5 & 13,8 \\
\hline \multicolumn{21}{|c|}{ ПАТ «ДТЕК Дніпроенерго» } \\
\hline $\begin{array}{c}\text { Криво- } \\
\text { різька }\end{array}$ & $\Pi$ & РШВ & 7,1 & 23,4 & 24,0 & 2,4 & 1,2 & 7,98 & 5350 & 9,9 & 53,0 & 39,2 & 2,2 & $|18,49|$ & 1087 & 0,79 & 34,0 & 11,8 & 10,4 & 53,8 \\
\hline $\begin{array}{c}\text { Придні- } \\
\text { провська }\end{array}$ & $\Pi$ & ШВ & 9,0 & 2,3 & 5,3 & 6 & 0,8 & 7,47 & 3823 & 5,9 & 22,7 & 35,9 & 1,4 & 8,96 & 715 & 0,49 & 33,8 & 14,1 & 6,4 & 23,2 \\
\hline апорізька & $\Gamma, Д Г$ & РШВ & 0,4 & 21,1 & 26,4 & 1,5 & 2,7 & 7,5 & 3420 & 19,9 & 68,1 & 38,5 & 2,8 & 15,6 & 1381 & 0,83 & 34,0 & 3,7 & 20,3 & 69,0 \\
\hline \multicolumn{21}{|c|}{ ПАТ «ДТЕК Західенерго» } \\
\hline $\begin{array}{c}\text { Бурштин- } \\
\text { ська } \\
\end{array}$ & ДГ & ШВ & 1,2 & 20,8 & 26,5 & 1,8 & 4,9 & 7,32 & 4225 & 35,5 & 150,0 & 39,8 & 2,7 & 28,38 & 1309 & 1,48 & 33,6 & 9,9 & 36,3 & 151,5 \\
\hline $\begin{array}{c}\text { Добро- } \\
\text { твірська }\end{array}$ & ДГ & ШВ & 1,4 & 20,8 & 26,3 & 1,7 & 1,2 & 7,28 & 3805 & 8,4 & 2,1 & 38,4 & 2,1 & 5,65 & 1059 & 0,23 & 34,2 & 1,0 & 8,6 & 32,3 \\
\hline $\begin{array}{c}\text { Ладижин- } \\
\text { ська }\end{array}$ & ДГ & IBB & 0,4 & 20,4 & 24,6 & 1,4 & 2,8 & 7,25 & 3037 & 19,9 & 0,5 & 9,1 & 2,2 & 20,75 & 1063 & 0,86 & 32,9 & 7,4 & 20,5 & 61,3 \\
\hline \multicolumn{21}{|c|}{ ТОВ «ДТЕК Східенерго» } \\
\hline Зуївська & $\Gamma, Д Г$ & $\mathrm{WB}$ & 0,3 & 0,7 & 27,8 & 1,9 & 1,6 & 7,38 & 4386 & 11,6 & 50,8 & 36,5 & 1,8 & 2,65 & 942 & 0,09 & 34,0 & 1,1 & 1,7 & 50,9 \\
\hline $\begin{array}{c}\text { Курахів- } \\
\text { ська }\end{array}$ & \begin{tabular}{|c|} 
пром. \\
продукт \\
$\Gamma, Д Г$ \\
\end{tabular} & ШВ & 2,0 & 17,9 & 36,4 & 1,3 & 3,4 & 6,27 & 3180 & 21,1 & 67,3 & 38,2 & 2,3 & 36,65 & 1089 & 1,52 & 34,1 & 2,2 & 22,1 & 68,8 \\
\hline $\begin{array}{c}\text { Луган- } \\
\text { ська }\end{array}$ & А, П & РШВ & 5,7 & 23,2 & 22,4 & 1,7 & 1,3 & 8,04 & 3718 & 10,2 & 37,9 & 40,2 & 1,3 & 4,42 & 600 & 0,11 & 33,7 & 2,3 & 10,3 & 38,0 \\
\hline Всього & & & & 21,3 & 25,6 & 1,7 & 26,7 & & & 200,0 & 795,6 & & & 60,8 & & 6,73 & & 153 & 44,2 & 802, \\
\hline
\end{tabular}

Таблиия 4. Інформація про якість та витрати палива, результати розрахунків питомих і валових викидів сухих димових газів та діоксиду сірки на вугільних ТЕС України у 2016 році

\begin{tabular}{|c|c|c|c|c|c|c|c|c|c|c|c|c|c|c|c|c|c|c|c|c|}
\hline \multirow[b]{2}{*}{ TEC } & \multirow[b]{2}{*}{ 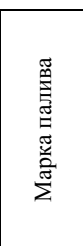 } & \multirow[b]{2}{*}{ 曾 } & \multirow[b]{2}{*}{$\begin{array}{l}a^{\circ} \\
\text { f }\end{array}$} & \multicolumn{8}{|c|}{ Для вугілля } & \multicolumn{4}{|c|}{ Для мазуту } & \multirow[b]{2}{*}{ 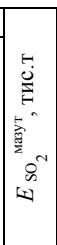 } & \multicolumn{2}{|c|}{ Для газу } & \multirow{2}{*}{\multicolumn{2}{|c|}{ 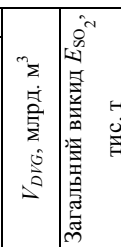 }} \\
\hline & & & & 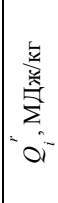 & $\therefore$ & $\therefore$ & 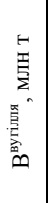 & 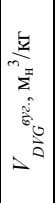 & 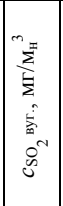 & 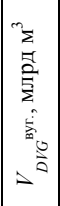 & 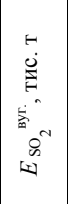 & 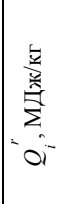 & $\begin{array}{c}a^{\circ} \\
-\infty\end{array} \mid$ & 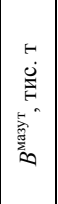 & 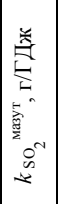 & & 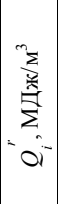 & 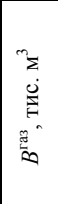 & & \\
\hline 1 & 2 & 3 & 4 & 5 & 6 & 7 & 8 & 9 & 10 & 11 & 12 & 13 & 14 & 15 & 16 & 17 & 18 & 19 & 20 & 21 \\
\hline \multicolumn{21}{|c|}{ ПАТ «Донбасенерго» } \\
\hline & А, П & ШВ & 3,7 & 23,3 & 24,2 & 1,8 & 2,5 & 8,3 & 3983 & 20,2 & 80,5 & - & - & 0 & - & 0 & 33,3 & 4,5 & 20,3 & 80,5 \\
\hline $\begin{array}{r}\text { Слс } \\
\mathrm{c}\end{array}$ & A & ШВ & 2,7 & 3,3 & 23,5 &, 7 & 1,6 & 8,4 & 3731 & 13,0 & 48,6 & - & - & 0 & 一 & 0 & 34,4 & 11,6 & 13,2 & 48,3 \\
\hline \multicolumn{21}{|c|}{ IAT «Центренерго» } \\
\hline $\begin{array}{l}\text { Вуглегір- } \\
\text { ська }\end{array}$ & ДГ & ШВ & 0,2 & 2,4 & 23,7 & 2 & 2,5 & 8,0 & 7143 & 20,1 & 143,4 & 38,6 & 2,1 & 1,4 & 1033 & 0,05 & 33,8 & 15,6 & 20,3 & 143 \\
\hline $\begin{array}{c}\text { Трипіль- } \\
\text { ська }\end{array}$ & $\Pi$ & ШВ & 6,2 & 1,9 & ,9 & 5 & 1,4 & 7,6 & 3358 & 10,9 & 36,5 & 40,0 & 2,3 & 26,5 & 1297 & 1,13 & 34,3 & 0,9 & 11,2 & 37,6 \\
\hline 3мії & $\Pi$ & РШВ & 7,5 & 2 & 4 & 9 & 1,1 & 7,9 & 4187 & 8,6 & 36,0 & 33,2 & 2,2 & 14,4 & 1260 & 0,61 & 4,1 & 1,5 & 3,8 & 36, \\
\hline \multicolumn{21}{|c|}{ ПАТ «ДТЕК Дніпроенерго» } \\
\hline $\begin{array}{l}\text { Криво- } \\
\text { різька }\end{array}$ & П & РШВ & 5,7 & 24,0 & 23,6 & 8 & 2,3 & 8,3 & 6214 & 19,3 & 119,7 & 39,9 & 2,5 & 1,4 & 1187 & 0,07 & 34,4 & 27,9 & 19,6 & 119 \\
\hline $\begin{array}{l}\text { Придні- } \\
\text { провська }\end{array}$ & А, П & ШВ & 7,4 & 23,5 & 22,3 & 2,0 & 1,4 & 8,0 & 4337 & 10,8 & 47,0 & 36,9 & 2,0 & 0,9 & 1008 & 0,03 & 34,1 & 30,8 & 11,2 & 47,0 \\
\hline апорізька & $\Gamma, Д Г$ & РШВ & 0,4 & 1,0 & 26,5 & 6 & 2,4 & 7,5 & 3722 & 17,7 & 65,8 & - & 二 & 0 & - & 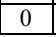 & 7,5 & 9,0 & 7,9 & 55,8 \\
\hline \multicolumn{21}{|c|}{ ПАТ «ДТЕК Західенерго» } \\
\hline $\begin{array}{l}\text { Бурштин- } \\
\text { ська }\end{array}$ & $\Gamma$, ДГ & $\mathrm{B}$ & 1,3 & 0,7 & 25,6 & 8 & 4,2 & 7,3 & 11 & 31,0 & 4,1 & - & - & 0 & - & 0 & 33,6 & 57,0 & 1,6 & 124,2 \\
\hline $\begin{array}{l}\text { Добро- } \\
\text { твірська }\end{array}$ & $\Gamma$, ДГ & IB & 1,5 & 21,0 & 27,8 & 1,9 & 1,2 & 7,4 & 4265 & 8,6 & 36,71 & - & - & 0 & - & 0 & 34,4 & 4,3 & 8,7 & 36,7 \\
\hline
\end{tabular}




\begin{tabular}{|c|c|c|c|c|c|c|c|c|c|c|c|c|c|c|c|c|c|c|c|c|}
\hline \multicolumn{21}{|c|}{ Продовжсення табл. 4} \\
\hline 1 & 2 & 3 & 4 & 5 & 6 & 7 & 8 & 9 & 10 & 11 & 12 & 13 & 14 & 15 & 16 & 17 & 18 & 19 & 20 & 21 \\
\hline $\begin{array}{c}\text { Ладижи- } \\
\text { нська }\end{array}$ & $\Gamma$, ДГ & РШВ & 0,4 & 20,9 & 24,4 & 1,5 & 2,2 & 7,4 & 3296 & 16,2 & 53,49 & - & - & 0 & - & 0 & 33,1 & 19,3 & 16,5 & 53,5 \\
\hline \multicolumn{21}{|c|}{ ПАТ «ДТЕК Західенерго» } \\
\hline Зуївська & $\Gamma, Д Г$ & РШВ & 0,3 & 19,9 & 27,1 & 1,6 & 1,8 & 7,1 & 3680 & 12,6 & 37,6 & 37,6 & 1,8 & 1,9 & 930 & 0,07 & & - & - & 46,3 \\
\hline $\begin{array}{c}\text { Курахів- } \\
\text { ська }\end{array}$ & $\begin{array}{c}\text { пром. } \\
\text { продукт } \\
\Gamma, \text { ДГ }\end{array}$ & ТШВ & 2,2 & 17,4 & 37,8 & 1,4 & 2,9 & 6 , & 3708 & 17,6 & 38,0 & 38,0 & 2,4 & 22,6 & 1119 & 0,96 & 34,5 & 9,0 & 17,9 & 66,1 \\
\hline $\begin{array}{c}\text { Луган- } \\
\text { ська }\end{array}$ & A, П & РШВ & 5,7 & 23,5 & 21,6 & 2,0 & 1,9 & 8,2 & 4220 & 15,5 & 34,4 & 34,4 & 1,3 & 2,0 & 723 & 0,05 & 40,8 & 14,6 & 15,7 & 65,5 \\
\hline Всього & & & & & & 1,9 & 29,2 & & & 222,0 & 968,7 & & & 71,1 & & 2,97 & & 216,2 & 225,3 & 976,6 \\
\hline
\end{tabular}

*РШВ - рідке шлаковидалення, ТШВ — тверде шлаковидалення.

Таблиия 5. Інформація про встановлену потужність ТЕС, відпуск електроенергії, ККД, питомі витрати умовного палива, що витрачається на відпущення 1 кВТ-г електроенергії, витрати та сірчистості вугілля і результати розрахунків валових викидів сухих димових газів та діоксиду сірки на вугільних ТЕС України у 2013-2016 pp.

\begin{tabular}{|c|c|c|c|c|c|c|c|c|c|}
\hline TEC & \begin{tabular}{|c} 
Встанов- \\
лена \\
потужність, \\
млн. кВт \\
(\% від \\
загальної)
\end{tabular} & $\begin{array}{c}\text { ККД, } \\
\%\end{array}$ & $\begin{array}{c}\text { Питома } \\
\text { витрата } \\
\text { у. П., } \\
\text { г/КВтг }\end{array}$ & $\begin{array}{c}\text { Відпуск ел. } \\
\text { енергії, } \\
\text { млрд кВтг } \\
\text { (\% від } \\
\text { загального) }\end{array}$ & $\begin{array}{l}S^{d}, \\
\%\end{array}$ & $\begin{array}{c}\text { В вугілля, } \text { мл т } \\
\text { (\% від } \\
\text { загаль- } \\
\text { ної) }\end{array}$ & $\begin{array}{c}V_{D V G}, \\
\text { млрд м } \\
\text { (\% від } \\
\text { загаль- } \\
\text { ного) }\end{array}$ & $\begin{array}{c}E_{\mathrm{SO}_{2}}, \\
\text { тис. т } \\
\text { (\% від } \\
\text { загаль- } \\
\text { ного) }\end{array}$ & $\begin{array}{c}\mathrm{SO}_{2}, \\
\Gamma / \mathrm{K} \mathrm{BT \Gamma}\end{array}$ \\
\hline \multicolumn{10}{|c|}{2013 рік } \\
\hline Всього & 21,94 & 31,3 & 394,8 & 71,1 & $1,93 *$ & 36,80 & 290,43 & 1221,97 & 17,2 \\
\hline 3 них А, П & $\begin{array}{l}12,21 \\
(55,6)\end{array}$ & 30,0 & 410 & $\begin{array}{c}34,7 \\
(48,9)\end{array}$ & 1,82 & $\begin{array}{l}17,73 \\
(48,3)\end{array}$ & $\begin{array}{c}146,97 \\
(50,6)\end{array}$ & $\begin{array}{c}573,28 \\
(46,9)\end{array}$ & 16,5 \\
\hline$\Gamma$, ДГ & $\begin{array}{l}9,73 \\
44,4)\end{array}$ & 32,1 & 379 & $\begin{array}{c}36,4 \\
(51,1)\end{array}$ & 2,04 & $\begin{array}{l}19,07 \\
(51,8)\end{array}$ & $\begin{array}{c}143,145 \\
(49,4)\end{array}$ & $\begin{array}{l}548,7 \\
(53,1)\end{array}$ & 17,8 \\
\hline \multicolumn{10}{|c|}{2014 рік } \\
\hline Всього & 22,3 & 31,2 & 397,7 & 62,0 & $1,82 *$ & 32,54 & 254,17 & 1013,42 & 16,33 \\
\hline 3 них А, П & $\begin{array}{l}12,44 \\
(55,8)\end{array}$ & 29,6 & 413,6 & $\begin{array}{c}28,6 \\
(46,0)\end{array}$ & 1,68 & $\begin{array}{l}14,54 \\
(44,7)\end{array}$ & $\begin{array}{l}121,42 \\
(47,8)\end{array}$ & $\begin{array}{c}433,35 \\
(42,8)\end{array}$ & 15,2 \\
\hline$\Gamma$, ДГ & $\begin{array}{c}9,86 \\
(44,2)\end{array}$ & 31,9 & 378,8 & $\begin{array}{c}33,5 \\
(54,0)\end{array}$ & 1,93 & $\begin{array}{c}18,0 \\
(55,3)\end{array}$ & $\begin{array}{l}132,75 \\
(52,3)\end{array}$ & $\begin{array}{c}580,07 \\
(57,2)\end{array}$ & 17,3 \\
\hline \multicolumn{10}{|c|}{2015 рік } \\
\hline Всього & 22,4 & 30,9 & 400,8 & 49,4 & $1,73 *$ & 26,70 & 204,17 & 802,36 & 16,2 \\
\hline 3 них А, П & $\begin{array}{l}12,50 \\
(55,8)\end{array}$ & 28,8 & 428,5 & $\begin{array}{c}15,6 \\
(31,7)\end{array}$ & 1,72 & $\begin{array}{c}8,36 \\
(31,3)\end{array}$ & $\begin{array}{l}68,43 \\
(33,7)\end{array}$ & $\begin{array}{c}257,61 \\
(32,1)\end{array}$ & 16,6 \\
\hline$\Gamma$, ДГ & $\begin{array}{c}9,90 \\
(44,2)\end{array}$ & 31,9 & 386,3 & $\begin{array}{c}33,8 \\
(68,3)\end{array}$ & 1,74 & $\begin{array}{l}18,35 \\
(68,7)\end{array}$ & $\begin{array}{c}135,44 \\
(66,3)\end{array}$ & $\begin{array}{c}544,76 \\
(67,9)\end{array}$ & 16,1 \\
\hline \multicolumn{10}{|c|}{2016} \\
\hline Всього & $22,33^{* *}$ & 30,7 & 403,7 & 52,7 & $1,91 *$ & 29,24 & 225,30 & 971,5 & 18,4 \\
\hline 3 них А, П & $\begin{array}{c}12,42 \\
(55,6)\end{array}$ & 29,1 & 423,8 & $\begin{array}{c}21,4 \\
(40,7)\end{array}$ & 2,0 & $\begin{array}{l}12,10 \\
(41,4)\end{array}$ & $\begin{array}{l}99,86 \\
(44,3)\end{array}$ & $\begin{array}{l}435,6 \\
(44,8)\end{array}$ & 20,3 \\
\hline Г, ДГ & $\begin{array}{c}9,91 \\
(44,3)\end{array}$ & 31,7 & 388,5 & $\begin{array}{c}31,3 \\
(59,3)\end{array}$ & 1,85 & $\begin{array}{l}17,14 \\
(58,6)\end{array}$ & $\begin{array}{c}125,44 \\
(55,7)\end{array}$ & $\begin{array}{l}535,9 \\
(55,2)\end{array}$ & 17,1 \\
\hline
\end{tabular}

*Середнє значення.

** У 2016 році реально працювало 20,6 млн кВт встановленої потужності ТЕС, 3 них 11,023 млн кВт $(53,4 \%)$ — потужності, що спалюють вугілля марок А та П, а 9,613 млн кВт (46,6\%) — потужності, що спалюють вугілля марок Г та ДГ.

Значення питомих викидів $\mathrm{SO}_{2}$ на вугільних ТЕС України в останні роки знаходяться на рівні 16-20 г/кВтг відпущеної електроенергії, проти 1,2 г/кВтг 
відпущеної електроенергії - нинішнього середнього європейського рівня. Це пояснюється використанням на ТЕС України вугілля із середнім і високим вмістом сірки та відсутністю на ТЕС установок ДДГ.

Крім того, експлуатація пиловугільних енергоблоків ТЕС відбувається на основі застарілих технологічних схем, які розроблялись у 60 -х роках XX століття. Середній ККД вугільних енергоблоків становить близько $31 \%$, причому значення ККД на ТЕС зменшуються з кожним роком (табл. 5), для порівняння - $45 \%$ при роботі у базовому режимі у розвинутих країнах. При цьому спостерігаються високі питомі витрати умовного палива (у. п.) на 1 кіловат годину відпущеної електроенергії, у 2015 р. вони були 400,8 г/кВтг, у 2016 р. 403,7 г/кВтг.

Отримані в результаті розрахунків та наведені в табл. $1-4$ значення питомих концентрацій $\mathrm{SO}_{2}$ на вугільних ТЕС показують вражаючу різницю існуючого рівня концентрацій і вимог європейських директив для діючих вугільних котлів. Рівень викидів $\mathrm{SO}_{2}$ на ТЕС України перевищує граничні значення в 8-18 разів. Для досягнення європейських екологічних показників необхідно різко підвищити ефективність існуючого пилоочисного обладнання та встановити нове сучасне газоочисне устаткування 3 рівнем ефективності $92-98 \%$.

ТЕС України, які мають джерела викиду, мають платити екологічний податок, питомі характеристики якого за 2013-2016 рр. приведені в табл. 6. У табл. 6 також наведені результати оціночних розрахунків загальної плати за викид $\mathrm{SO}_{2}$ у ці роки на ТЕС України.

Таблиия 6. Оціночні розрахунки загальної плати за викид $\mathrm{SO}_{2}$ на ТЕС України у 2013-2016 pp.

\begin{tabular}{|c|c|c|c|c|}
\hline \multirow{2}{*}{ Параметр } & \multicolumn{4}{|c|}{ Роки } \\
\hline & $2013^{*}$ & 2014* & $2015^{*}$ & 2016 \\
\hline $\begin{array}{c}\text { Відпущено електроенергії на ТЕС України, } \\
\text { тис. кВТг }\end{array}$ & 71115,20 & 62032,68 & 49397,80 & 52726,28 \\
\hline $\begin{array}{c}\text { Викиди } \mathrm{SO}_{2} \text { на ТЕС України (за нашими } \\
\text { розрахунками), тис. т }\end{array}$ & 1221,97 & 1013,42 & 802,36 & 971,50 \\
\hline $\begin{array}{c}\text { Ставка податку за викид } \mathrm{SO}_{2} \text { за Податковим } \\
\text { кодексом України, } \\
\text { грн/т Свро/т } \\
\end{array}$ & $\begin{array}{c}1078,28 \\
101,61 \\
\end{array}$ & $\begin{array}{c}1162,12 \\
73,94 \\
\end{array}$ & $\begin{array}{c}1165,34 \\
48,10 \\
\end{array}$ & $\begin{array}{c}1968,81 \\
69,59 \\
\end{array}$ \\
\hline $\begin{array}{c}\text { Розрахункова величина загальної плати за } \\
\text { викиди } \mathrm{SO}_{2} \text { на ТЕС України, } \\
\text { млрд грн } \\
\text { млн євро }\end{array}$ & $\begin{array}{c}1,32 \\
124,2\end{array}$ & $\begin{array}{l}1,18 \\
74,9\end{array}$ & $\begin{array}{l}1,04 \\
42,9\end{array}$ & $\begin{array}{l}1,91 \\
67,6\end{array}$ \\
\hline
\end{tabular}

* Діяла пільгова ставка 0,75 .

Ставка податку за викид $\mathrm{SO}_{2}$ згідно зі ст. 243 Податкового кодексу України у 2016 р. досягла 70 євро/т. У 2017 р. цей екологічний податок складав 2204,89 грн/т або 73,49 євро/т, у 2018 р. — 2451,84 грн/т або 70,05 євро/т (в цінах січня 2018 р.). Розрахункова величина загальної плати за викиди $\mathrm{SO}_{2}$ на ТЕС України у 2016 р. досягла 1,9 млрд грн або 67,6 млн євро. Зростання плати за викиди діоксиду сірки згідно НПСВ до 200 євро/т призведе до суттєвого збільшення цієї плати [7]. 
За відомими з літератури планами з реконструкції та/або модернізації, демонтажу та виведення 3 експлуатації генеруючих компаній встановлена потужність енергоблоків ТЕС України, за нашими оцінками, складе 16,7 млн. кВт. Це відповідає оцінкам наведеним в Енергетичній стратегії України на період до 2035 року. Капітальні затрати встановлення на ТЕС устаткування 3 ДДГ досягають 200 євро на кВт встановленої потужності. Тому загальна оціночна вартість таких робіт - 3,34 млрд євро. Застосування практики спорудження одного скрубера 3 «мокрою» димовою трубою на декілька енергоблоків зменшить питомі капітальні та експлуатаційні затрати.

\section{Висновки}

1. Значення питомих концентрацій діоксиду сірки в сухих димових газах на ТЕС України у 2013-2016 pр. залежно від марки палива та способу шлаковидалення в котлі були в діапазоні 2500-7200 мг $/ \mathrm{M}_{\mathrm{H}}{ }^{3}$. Концентрація діоксиду сірки в димових газах для працюючих вугільних котлоагрегатів після 01.01.2018 повинна бути не вище $200 \mathrm{мг} / \mathrm{M}_{\mathrm{H}}{ }^{3}$, а для нових $-150 \mathrm{мг} / \mathrm{M}_{\mathrm{H}}{ }^{3}$, як цього вимагає наказ Мінприроди України від 16.02.2018 № 62 та Директива 2010/75/EU про промислові викиди ставить. Це вимагатиме впровадження на ТЕС сучасних ефективних технологій ДДГ.

2. Сучасні технології десульфуризації, що здатні забезпечити ступінь очищення не менше ніж 96\%, поки не знайшли поширення на ТЕС України через їх високу вартість та відсутність промислового досвіду. Широке розповсюдження вапняку та отримання гіпсу як субпродукту ставлять технології мокрої вапнякової десульфуризації на чільне місце, незважаючи на високі капітальні затрати (до 200 дол. США/кВт). Поширена практика спорудження одного скрубера 3 «мокрою» димовою трубою на декілька енергоблоків суттєво зменшує питомі капітальні та експлуатаційні витрати, оскільки вапняк $\epsilon$ дешевим сорбентом.

3. Перспективною є напівсуха аміачна десульфуризація, коли на виході утворюється сухий порошок сульфату амонію як мінерального добрива. Зважаючи на малий розмір частинок сульфату амонію, вихідним пиловловлювачем має бути рукавний фільтр. Суху десульфуризацію слід застосовувати в котлах киплячого шару для очищення димових газів від сполук сірки.

\section{Література}

1. Протокол про приєднання України до Договору про заснування Енергетичного Співтовариства [закон України: від 15.12.2010 № 2787-VI] // Офіційний вісник України. 2011. — № 1.- С. 1 .

2. Меморандум між Україною та ЄС про взаєморозуміння щодо співробітництва в енергетичній сфері // Офіційний вісник України - 2006. — № 13. — С. 453.

3. Меморандум про взаєморозуміння щодо Стратегічного Енергетичного Партнерства між Україною та Європейським Союзом спільно 3 Європейським Співтовариством 3 атомної енергії // Офіційний вісник України - 2017. — № 80.- С. 603.

4. Про Загальнодержавну програму адаптації законодавства України до законодавства ЄС [закон України: від 18.03.2004 № 1629-IV]//Офіційний вісник України. —2004. — № 15. — C. 30 . 
5. Directive 2010/75/EU of the European Parliament and of the Council of 24 November 2010 on industrial emissions (integrated pollution prevention and control) // Official Journal of the European Communities. - 2010. - L. 334. - P. 17-119.

6. Наказ Міністерства охорони навколишнього природного середовища України від 16.02.2018 № 62 «Про внесення змін до наказу Мінприроди від 22 жовтня 2008 року № 541» //Офіційний вісник України. — 2018. - № 28. - С. 290.

7. Commission implementing decision (EU) 2017/1442 of 31 July 2017 establishing best available techniques (BAT) conclusions, under Directive 2010/75/EU of the European Parliament and of the Council, for large combustion plants // Official Journal of the European Communities. - 2017. - L. 212. - P. 1-82.

8. Вольчин I.A. Перспективи впровадження чистих вугільних технологій в енергетику країни / I.А. Вольчин, Н.I. Дунаєвська, Л.С. Гапонич, М.В. Чернявський, О.I. Топал, Я.І. Засядько. - Київ : ГНОЗІС, 2013. - 310 с.

9. Майстренко О.Ю. Сучасний стан вугільної енергетики України та перспективи їі оновлення і розвитку / О.Ю. Майстренко, О.І. Топал, Л.С. Гапонич // Наукові праці Національного університету харчових технологій. - 2010. - № 32. - С.43- 47.

10. Вольчин I.A. Розрахунок параметрів димових газів вугільних теплових електростанцій на основі характеристик твердого палива / I.А. Вольчин, Л.С. Гапонич // Энерготехнологии и ресурсосбережение. - 2016. — № 1. - С. 49-55.

11. Volchyn I., Haponych L. Engineering method for calculating the parameters of flue gas parameters of coal-fired thermal power plants based on solid fuel characteristscs // Ukrainian Journal of Food Science. — 2016. — Volume 4. Issue 2. — P. 327-338.

12. Баториин B.A. Решение экологических проблем в угольной энергетике США / В.А. Баторшин, В.Р. Котлер // Энергохозяйство за рубежем. - 2014. - № 1. - С. 15-20. 13. Kohl A.I. Gas purification. $5^{\text {th }}$ ed.//Houston: Gulf Publishing Company. - 1997. - 1403 p.

14. Вольчин I.A. Технології сіркоочищення вугілля // Энергосбережение. - 2013. № 2. - C. 14-17.

15. Вольчин I.A. Про використання карбаміду в схемах напівсухого сіркоочищення // Енергетика та електрифікація, 2011. - № 9. - С. 3-12.

16. Вольчин И.А. Применение аммиака в технологии полусухой десульфуризации // Инновации и инвестиции. - 2014. — № 6. - С. 119-123.

17. Вольчин I.A. Використання технології напівсухої амоніакової десульфуризації димових газів на вугільних електростанціях / I.А. Вольчин, О.М. Коломієць // Наука та інновації. - 2017. - № 4. - С. 21-29

18. Volchyn I. Estimate of the sulfur dioxide concentration at thermal power plants fired by donetsk coal / I. Volchyn, L. Haponych // Power Technology and Engineering. - Vol. 48, \# 3. 2014. - P. 218-221.

19. Методика определения валовых выбросов загрязняющих веществ в атмосферу от котельных установок ТЭС. РД 34.02.305-98.- Москва : ВТИ им. Ф.Э. Дзержинского, 1998. - $70 \mathrm{c}$.

20. ГКД 34.02.305-2002. «Викиди забруднюючих речовин в атмосферне повітря від енергетичних установок. Методика визначення». Київ : ОЕП «ГРІФРЕ», 2002. — 42 с. 